\title{
Early Marriage : Ethnographic Study in North Securai Village Babalan District Langkat Regency
}

\author{
Yona Tusiana and Fikarwin Zuska \\ University of North Sumatra \\ fikarwinzuska@gmail.com
}

\begin{abstract}
Keywords : Early Marriage, youth.
Abstract: $\quad$ This study discusses the lives of married couples, from before marriage until after marriage. The purpose of this study is to describe why early marriage occurs in North Securai Village, Babalan Sub-District, Langkat Regency, and also the implications of early marriage on her home life. This research uses ethnographic methods. Methods used in digunakan data collection are observation of participation and in-depth interviews. The results of the study are many things that are the cause of early marriage, such as from their own desires until the marriage is forced to be done, as well as because of MBA (Married By Accident).
\end{abstract}

\section{INTRODUCTION}

Man is a social being who essentially needs others to be able to survive and needs to maintain human existence in the presence of a keturuan by performing marriages. Marriage is one of the most important stages throughout the human life cycle called stage a long the life cycle. The stages that exist throughout human life are such as ind infants, weaning period, childhood, adolescence, puberty, post-marriage, old age and so on (Koentjaraningrat, 1982).

One such stage will indirectly change the behavior of the person/person itself, which can be seen when the person/person is in a legal marriage. Therefore, marriage is one of the most important stages in the cycle of human life, as a tool of a community to continue the continuity of its group.

Marriage is also a cultural medium in regulating inter-human relationships of different sexes. Marriage aims to achieve a more mature level of life and in some tribal societies today.

The phenomenon of young marriage is still found in many parts of the world. One of the countries in the world where marriage rates at a very young age is India by making it one of the social issues. According to Equality Now, UNFPA says 47percent of girlsinra hukuIndia are married before the age ofskipun melawannya namun 15 , which is against Indian law- religious and personal law.m, me There are also some countries on the Africancontinent with high rates of youngmarriages, such as in Niger where theUnited NationsPopulations Fund (UNFPA) estimates that one in three girls are married under the age of 15 and that about 75 percent of women aged 20-24 marry before reaching the age of 18 for one of the biggest reasons for the food crisis. In addition, there is also the country of Chad (Central Africa) which according to a 2013 Ford Foundation report that cultural traditions, conflict, parental confusion over the large number of children, the failure of the education system are the reason for the practice of early marriage in this country is still ongoing.

As for the national figures,Sulawesi Barat is the highest number holder. In the January 2017 report "Child Marriage in Indonesia",which was issued by the Central Bureau of Statistics (BPS) and the United Nations Children's Fund (UNICEF) in January 2017, 22.82 percent married before the age of 18 (BPS, 2015). There are 20 provinces with a higher prevalence of child marriage than the national figure (22.82 percent). The five provinces with the largest prevelence figures are West Sulawesi (34.22 percent), South Kalimantan (33.68 percent), Central Kalimantan (33.56 percent), West Kalimantan (33.22 percent), and Central Sulawesi (31.91 percent). Then in North Sumatra Province, btargeted a population census conducted by BPS Sumut mentioned that 10 to $11 \%$ of women of childbearing age (WUS) married at the age of 16 in 2010, and according to the description of BPS Sumut itself at least, there are 
$47.79 \%$ of women in rural areas mating under the age of 16 , while the city reached $21.75 \%$ in 2011 (BPS, 2011).

Based on data of the National Population and Family Planning Agency (BKKBN) of North Sumatra Province in 2014 the number of PUS (Couples of Childbearing Age) with the age of wife under 20 years as many as 75512 people (Family Data In 2014). ASFR data for 15-19 years in 2012 in Deli Serdang amounted to 15 per 1000 births (BPS, 2012). Early marriage in Deli Serdang Regency is still quite a lot, this can be seen from bkkbn data of North Sumatra Province (Family Data In 2014) which shows the number of PUS with the age of wife under 20 years as many as 4375 people. Based on the results of Susenas 2008-2010 and the 2010 population census (CPM Catalog: 4103014) that the percentage of young women's marriage in Deli Serdang Regency is 31\% and in Bangun Purba sub-district as much as $29 \%$.

The number of early childhood marriages of Indonesian women in $\mathrm{Kab} \mathrm{L}$ is expectedtoincrease. He said information from a source from a national Population and Family Planning Agency (BKKBN) said the diamond was considered a failure in regulating population growth rates. Because, BKKBN 2000-2012, it is known that the age of early marriage increased from an average age of 19.8 years to 19.2 years. In fact, the age standard that BKKBN emphasizes for a woman ready to marry is 21 years. The younger a woman gets married, the longer the reproduction period will last. Meanwhile, BKKBN langkat is judged to be slow in socializing to residents in Kab Langkat.

According to village heads and researcherre records during the study, generally those who do marriage at a young age no longer go to school, especially for women, so the opportunity to get a higher education becomes closed resulting in the reclusive opportunity to get a better formal job that provides a promising income or that can provide better representation (Mahfudin \& Waqi'ah, 2016). When a person has a low income or does not havea problem, it willhave implications on the life of the household that performs marriage at a young age namely economic problems as well as knowledge of how to be a good parent.

Viewed from the medical side also causes a lot of adverse effects. Women who get married at a young age have a better time withthe risk of pregnancy.. The risk of death from pregnancy is twice as high in adolescent girls ages 15-19 thanngan in women aged 20-24 tahun. It also has negative implications in prospective babies such as low birth weight (BBLR), premature and other babies (Andrian \& Kuntoro, 2013).). Judging by the socioeconomic aspects, women will continue to depend on their husbands, women will only be relied upon in domestic affairs, such as cooking, washing, and child care and will not be involved in decision-making because they are considered uneducated (Dafeni, et al, 2017).

However, in Islam, which is embraced by most indonesians, including North Securai Village, Babalan District, LangkatRegency, can be done when a person has reached aqil baligh.. In Indonesia, according to the Marriage Act of 1974, marriage is only permitted if the male party reaches the age of 19 (nineteen) years and the woman has reached the age of 16 (sixteen) years (Darondos, 2014).). Hal will have a bad effect on the couple because psychologically and bilogistally, because young married couples are considered immature to be able to conceive, give birth and then are not ready to face household problems (Rifiani, 2011; Minarti, 2014). According to Mufidah (Sumbullah \& Jannah, 2012), the ideal age of fertilization in female reproductive organs is at least 21 years old.

Based on interviews with some families who allow their children to have early marriages, mentioning some reasons such as they feel more relieved when their daughters decide to marry, in economic terms and in terms of supervision. According to the informant Zulkarnain said that he was easier to ngangon oxen than to look after one girl. Some have also revealed that for what it is in high school, if in the end girls will also descend into kitchens and wells.

Early marriage also has implications for the couple in living a home life after marriage, some of which are sex, domestic economics, domestic violence and maternal and child care (Alfina, et al. 2016; Setiawati, 2017; Sumbullah \& Jannah, 2012).

The conclusion is that early marriage aims to legalize a relationship to legalize a relationship in order to avoid adultery that can cause disgrace and embarrass the family. However, if reviewed from health and psycholgis aspects, that getting married, pregnant, and giving birth can harm the reproductive organs of women (Andrian \& Kuntoro, 2013; Sumbullah \& Jannah, 2012). Dari psychic aspect, a woman is considered to be ready to be a mother at the age of 21 years, according to her psychological maturity (Sumbullah \& Jannah, 2012).).

While from the socioeconomic aspect, young married couples will find it difficult to get a better formal job, thus impacting on low economic income (Mahfudin \& Waqi'ah, 2016). Thus impacting on his 
household life such as KDRT which can be caused by several external and internal factors such as faktor demography which include the age of first marriagewife, family income, wife education, wife employment status, wife knowledge and gender inequality (Huda, 2005; Sutikno, 2006).

\section{RESEARCH METHODS}

Penelitian is explosive which will then be presented in ethnographic and qualitative descriptive design that aims todescribe in detail how early marriage still occurs, what factors lead to early marriage and the implications for the life of an early marriage partner in hishousehold. descriptive research aims to accurately describe the properties of an individual, the circumstances or symptoms or a particular group or to determine the frequency or spread of a symptom or the frequency of the relationship between a symptom and other symptoms in a society (Koentjaraningrat, 1989).

The type of research that will be done is qualitative with ethnographicmethods, where this research intends to understandphenomena about what is experienced by research subjectse.g., behavior, presepsi, motivation, action, holistically and by way of description in the form of words and language, in a special context that is natural and by utilizing various scientific methods.

This study uses a participatory observation technique, in which the researcher observes a symptom in his position as a person involved in the activities of the conscientiouscommunity, i.e. the researcher participates with the activities he observes. Some of the things that researchers observed were such as: the place of the tingal, the bedroom, the possessions, the appearance of the self, how to interact with the partner and so on.

While the interview used is an in-depth interview that explores information more deeply, openly, firmly and freely but in focus on what will be researched. In addition, secondary data is also used, namely data related to the aspects studied that are sourcedfrom books, magazines, articles, both mass and electronic media that are considered synchronous and relevant related to the discussion of the research.

\section{RESULTS AND DISCUSSIONS}

The marriage took place in North Securai Village, closely related to the ecological structure that has a very large rice field area whereebanyak 1,830 residents work as Farmers who require them to work from sunrise to sunset, dan and so can not focus on taking care of their families. This makes them have to find a wife who should be able to take care of husband, childand household in a lateway, which underlies education is not very important for women, the most important thing is the skill in taking care of the household. Since childhood, a daughter has begun to be taught to cook and clean the house,karena when her father and motheraresawah, then it is the daughter who must take care of everything in the house.

From informants who did weddings at a young age, some people have finished high school and some just finished junior highschool. According to them, women will eventually follow wherever the husband will go. According to the male informant bang "B", the husband of "E" who married his wife when he finished high school and the wife's parents do not mind for his son to be married soon, said that there is still a lot of work to be done just by finishing high school,where the village is still spacious to work on and make money, while to eatthe wife can grow vegetables at the back of the house.

The predominantly Javanese community in North Securai village has its own view ofmarriage, which is not unusual. The parents of prospective grooms and women do not give difficult conditions because the important thing is the purpose of marriage itself is to authorize the relationship of their children into a husband and wife.

There are several reasons put forward to justify the marriage:

a. Permissive Culture of Courtship

Masyarakat Securai Utara is not a permissive group on courtshipculture, where parents argue dating will only lead tonegativity, so many of them are "marry only". Like "N" the residents of North Securai Village RT 3 who only finished junior high school and do not want to go to school anymore, who have girlfriends in the hamlet of pasar lebar. He was often picked up by his girlfriend "U" and taken to his house. Many neighbors have warned that "U" soon marries "N" because he has been brought home often, but "U" reasoned he did not have a permanent job.

b. Difficulty Looking After Girls

In this case, ""B"and "N" are examples of adolescent associations that cause them to have to undergo an MBA (MarriedBy Accident). Since junior high school "N" has been unruly, and both parents have jobs that make it difficult for her to control her child's relationship outside the home. In high school, "N" became acquainted with Bambang who was an alumnus of his school through social media. They 
often walk together and the parents " $\mathrm{N}$ " never forbid because Bambang always asks permission if he wants to take his child away. But in the second grade of high school, "N" confessed that she was pregnant, which they eventually married and made her quit school. According to Ibu "N" her son is still not ready to be a Mother, where his son is still often abandoned by wanting to spend time outdoors, while her husband rarely comes home because of work.

c. Javanese perception of marriage

According to javanese people living in the area, marriage should not be used as a burden by asking for a dowry and high delivery, because the point is to legalize a relationship. Nor do they question the work of their future husbands, because the sustenance has been arranged by God.

Furthermore, there are 2 causes of early marriage, namely dilamar and MBA (Married By Accident).). In addition, there are also several other related factors.

1. To be married

The Javanese community in North Securai village has its meaning about the concept of application where if the application of a man who comes to his family is not accepted, then their daughter will long accept a new application or extended practice. Therefore, abstinence for them rejected the application. A strong reason why a girl is a girl is out of school. The low level of education and knowledge of parents, children and local communities leads to a tendency to marry children who are minors and are not accompanied by long thoughts about the consequences and impact of the problems faced. There are still many parents who think if a girl is late to take care of the house and cook, the child is suitable for the married.

Schools are not challenging to find in the area, but not all parents consider the school necessary. Lingkungan education is essential in determining a student's future because it impacts his or her future life. Like the "S" who during high school enrolled in Madrasah Aliyah Al-Ikhlas, North Securai Village, where the school in the place can be while working that does not require his students to come every day but must take the exam as it should. After graduating, she was out of work and took a few months to marry the man who proposed to her because, according to her parents, she was fit to marry because she could cook and take care of the household.

\section{Economic}

Economic problems are often the main problem of performing marriages at a youngage. "W", a 16-yearold girl, had just had her wedding on June 23, 2018 at her parents'residence Dusun PasarLebar, by marrying a 25-year-old man who worked in her family farm. The economic situation forced her parents to approve the marriage, where her father worked as a family, her mother was only a housewife who took care of her three younger sisters. He only went to school until MTs because no one helped his mother take care of her younger siblings at home. After marriage, "W" is taken by her husband to her parents' house which then impacts on the family economy where $\mathrm{W}$ " has reduced her family's economic burden.

3. Not Working

Divided into 2 is not working on his own volim where he will help his parents at home, and not work because he does not get a job because he does not have a higher education and good skills.

4. Asokan

Arisan party or asokan by javanese people is to reduce the burden of every family that will do the event at home. When family A holds an event, then families B, C, and D will "save" the staples in family home A. When si B saves $100 \mathrm{~kg}$ of rice for example, then when family B getsmarried or holds an event, then family A will return the sameamount, bsoas muchas a, and all based on the ability of each family. Tradisi can affect the marriage that occurs. As revealed by Wak Pon, who married his son at a young age even though his son did not want to. Besides because her son has no activities at home, his desire to quickly dance asokan is also the reason that he has saved a lot of asokan in his group, but his son has not been married, so he has not been able to attract the asokan. Finally Siti was married first, stepping over her brother who was at work at the time.

5. MBA (Married By Accident)

They are getting pregnant before marriage is a disgrace to the family. So when the parents find out the girl is pregnant, the parent immediately marries her child to the man who has impregnated her, like the "R" who was forced to be married by her parents to her class brother "Z" because she was pregnant first. The busyness of parental work causes them to hang out more often with their friends, and parents also less apply the rules of the night time.

Then, there are implications of early marriage for early marriage perpetrators, especially in terms of continuing education. Like the informant "W" who decided to go to school and get married at a young age. He is only a junior high school graduate whose school is considered not very good among the local community. Students are allowed to keep working and not attend lesson hours, but still take exams as usual. Currently "W" is married and lives with his inlaws which has reduced his family's economic burden. But she no longer wants to go to school 
because she is married and her job is just to take care of her husband and help with her work. In contrast, the informant "R" wanted to go to college but could not because he already had two children, where he was forced to marry because he was pregnant first.

Furthermore, there are also implications of early marriage on the household economy of early marriage. Like "R" bu Tuti's young son because he got pregnant first. Currently husband " $\mathrm{R}$ " is only a building laborer with a salary of 70 thousand / day, which costs enough for his family because for the cost of daily meals is still helped by families of both parties. The people of North Securai village are people who are not afraid of the poor. According to some informants, the important thing is that he can eat every day. It doesn't matter what side dishes are eaten.

However, some make the economy a domestic problem. Like kak "A", the mother of "W" who was also married young at the age of 15 because she no longer attends school. After marriage, she stayed in her in-laws' home and often quarreled with her husband for not having a permanent job. Then she divorced from her husband and remarried bang "E" who also had no permanent job, only construction workers or laborers in the rice fields. However, she does not take any dizziness about her husband's income because she thinks her job is to take care of only her three children.

The next implication is on any of KDRT or domestic violence. In this study, there have been no found cases of domestic violence in all informants. However, when researchers to the Village Office came forward with several reports to file for divorce resulting from KDRT, which also stemmed from economic problems.

Then, there are also implications of marriage to mother and son care in early marriage perpetrators. The treatment of pregnant women is done by checking the womb to posyandu, as well as through several beliefs such as doing mitoni (nujuh bulan) event so that the mother and baby can be born safely, healthy without any shortage. Ada also believes that javanese people in North Securai village that carry sharp objects such as pins, scissors and bangles can avoid the disturbance of delicate creatures.

One of the "R" informants said that pregnancy screening is not essential, Awareness to take care of her and her baby only at the behest of her parents. The husband never accompanied her to check on her pregnancy because she was busy working and rarely asked about it. According to her, she was checking the pregnancy in the midwife. It takes a long time because through the stage an-stage where it is all questioned to the mother directly or the neighbors who have become pregnant and give birth. It also happens to the "N". If it were not for her parents' coercion, she would not have checked her pregnancy with a midwife.. There has been no realization that caring for herself and caring for her future children is essential.

As for childcare, Securai Utara, the community is still very compliant with parenting habits before "off the kitchen", whichis the time when the baby's age is not even 40 days and has not been allowed to be taken out of the house. After the care of the newborn, it is time for the first time. According to informants "S" and "A" who no longer live with their parents, they are usually members of whatever food their child wants to eat. To start MPASI, usually they give bananas that are slit with a spoon. MPASI is also not done when the age of 6 months if the child has asked to eat yes in love alone, which is important do not be harsh. If the child is sick from mise eating such as diarrhea or constipation, he thinks it is natural because ordinary children are sick.

As a toddler, all the researchers said that they would enroll their children in schools with relatively cheap enrollment fees and monthly fees, or even the cheapest because it was an early education that did not learn much.

\section{REFERENCES}

Andrian \& Kuntoro. 2013. Spontaneous Abortus At Early Childhood Marriage.. Journal of Biometrics andPopulation, Vol 2, No. 1,, July 2013.

Dafeni, Septi Rani, etal. Relationship of Several Factors Causing Domestic Violence (KDRT) In Pus Wives In Tinjomoyo Village Banyumanik District year 2016. Journal of Public Health (eJournal) Volume 5, Number 4,October2017 (ISSN: 2356-3346)..

Darondos, S. 2014. Marriage of Minors and Their LegalConsequences. Lex Et Societatis, Vol. II/No. 4, No. 4, Volume 2.

Koentjaraningrat. 1982. Some Points of Social Anthropology. Dian Rakyat. Jakarta.

Koentjaraningrat. 1989. Introduction to Anthropology. Ethnographic Staples II. Rineka Cipta. Jakarta.

Minarti, May, et al. 2014. Picture of the Biological and Psychological Impact of Early Marriage In Mundang Village, Bergas District, Semarang Regency. Jurnal Child Care. Volume 2, No. 2,November 
Sumbullah, Umi, et al.2012. Early Marriage And Its Implications on Family Life In Madura Society (Legal And Gender Perspective). Egalita Jurnal Kesetaraan dan Gender, Volume VII No. 1,, January 